\title{
DEVELOPING METHODICAL COMPETENCY IN FUTURE TEACHERS
}

\author{
Lyudmyla Lyktei \\ Methodist, teacher of the Ivano-Frankivsk college Vasyl Stefanyk Precarpathian National University \\ https://orcid.org/0000-0001-7348-4286, e-mail: L.liktej@ukr.net
}

\begin{abstract}
.
Relevance: urgency of the research consists in the need to justify the methodological foundations of the method competence formation of the future teacher via the method competence development of teachers of humanities in pedagogical colleges within teaching process of the humanitarian direction disciplines.

The purpose of the research consists in justifying and highlighting the problems of method competence formation of future teachers in pedagogical institutions of professional pre-higher education in Ukraine.

Methods: theoretical (learning and analysing of philosophical, psychological and pedagogical literature, comparison and generalization of theoretical concepts of pedagogical experience of humanities teachers, priority researchers' ideas about solving the problem with the future teachers' method competence formation); empirical (self-estimation methods, methods of expert evaluation); statistical (partial analysis of test of statistical hypotheses).

Results. In the article, a number of opinions of scholars are highlighted, which create a combination of the results of the method competence development, methodic experience and personality traits, which represent a professional balance and integrative educational course. A number of hypotheses that are known to scientific intelligence regarding the method competence formation of future teachers are analyzed, their essence is considered. This made it possible to set basic requirements for the method competence development from the origins of its creation to professional application in practice. Obviously, the effective method competence formation in future teachers is, first of all, based on motivational beliefs, personal awareness of the chosen profession importance, the desire to acquire professional and methodical experience. At the same time, the method competence development of the teachers of the humanities in pedagogical colleges, the enhancement of professional qualities, the methodological culture, the desire to introduce and apply innovative working methods in the educational process, focused on the development, training, and education of the novice teacher, are of great importance.

Conclusions. Methodological principles of formation and development of future teachers' method competence should be based on the formation of professionally important and paramount qualities for the proper realization of the educational process, as well as on the understanding and awareness of the essence, content, goals, and objectives of pedagogical education. Future educators should also possess a range of pedagogical knowledge, methodological skills and competences, and master the methods and ways of solving pedagogical tasks that contribute to the pursuit of pedagogical qualification, professional and method competences.
\end{abstract}

Keywords: method competence, of method competence development, teacher, educators, and education.

Introduction. On the ground of the orientation of the Ukrainian educational vector to the world and European pedagogical community, we reckon one of the priorities of the education development is its improvement, modernization, integration, improving the quality of future teachers' vocational training. Such changes are related to a number of reasons: reinforcement of the level of competitive ability and competitiveness of the future specialists, their pedagogical qualification, value orientations, methodological culture, which influence the teacher's methodical formation in accordance with current requirements.

Considering the above, it is an important task for teachers of the humanities to choose the right personcentered learning strategy, which will create 
pedagogical conditions for the proper problem solution with the method competence formation of the future teacher. In this regard, a properly chosen personoriented strategy and professional training practice, adequate content of higher education within public needs in culture, and a student in self-creation and educational and professional creativity, should add up to the qualitatively new provision (Kucheriavyi, 2015, p. 50). Modern processes of reforming professional pre-higher education give impetus to active purposeful continuous professional and methodological growth, which helps to find new ways of formation, improvement and of method competence development both for teachers in pedagogical colleges and students of pedagogical specialties.

We believe that future teachers need a flexible adaptive trajectory, a systematic continuous search for ways of self-realization in order to ensure the proper functioning of pedagogical education. Within the implementation of educational process in the enriched educational environment the teachers are required to show readiness for innovative activity, and willingness to experiment, to have knowledge of innovative working methods and experience of their promotion, to be competent of practical skills of mastering pedagogical innovations (Zamkova, 2015, p. 7). In turn, the ability to operate with modern technologies and teaching aids contributes to comprehending the philosophy of modern pedagogical education and the expression of key competences.

Sources. In the process of making a detailed analysis of methodological publications, scientific works and encyclopedic sources, the results of research that are directly related to the future teachers' method competence provoke a particular interest. The number of works indicates a great interest in this matter. Fundamental research in this direction belongs to such scientists as M. I. Mykhniuk, I. M. Novyk, H. L. Stefanova, N. A. Tarasenkova, T. N. Hushchyna, L. V. Koval, N. D. Kuchuhova, G. L. Lukankinii, T. A. Zahryvna, V. I. Zemtsova, O. V. Tumashova and others. Considering the importance and effectiveness of the topic the creation of conditions that are necessary for the formation of methodological competence of the future teacher, has particular important implications.

The purpose of the study is to justify and theoretically comprehend the regularities of the method competence formation process of future teachers in pedagogical institutions of professional higher education.

Results and discussion. The professionalism and the teacher's method competence, as an integral component of professional competence, is manifested in the self-awareness, the improvement of professionally methodological development and professional growth. This is precisely why the future teacher, who wants to keep their finger on the pulse, must be fully aware of the importance of theory and practice knowledge, the method competence formation and development. In the field of higher pedagogical education, the term "method competence" is interpreted in different ways, however, aiming at the same truth. According to the interpretations of researchers, method competence is the actualization process of our capabilities, the intellectual ability development using intellectual work in the professional activity process, which is manifested in the teacher's scientific methodological and the learning and teaching activity, the knowledge of methodological and theoretical bases of teaching methods in various subjects, conceptual bases of the teaching techniques structure and content, the ability to apply knowledge in pedagogical and social activities, perform basic professional and methodological functions (Zabolotna, 2013, p. 68). Methodical competence is a complex integrative formation that is a combination of methodological training, skills and pedagogical activities necessary for the effective implementation of the learning process, methodological experience gained in the process of professional activity and teacher's personal traits (Simonenko, 2013, p. 6). The main component of pedagogical competence provides the ability to recognize and solve methodical tasks that appear within pedagogical activity. After its formation and development the best results of pedagogical activity is achieved, based on the emergence of new, personal experience (Halai, 2010, p. 1-9). It should be stated that the analysis of Ukrainian and foreign researchers' scientific studies testifies to the fact that in the system of pedagogical education the term "professional competence" is frequently used. It fully and thoroughly reveals the methodological phenomenon essence and corresponds to the concept of "methodological competence" used in the Ukrainian education environment.

The researchers' opinion is of interest to us, because they believe that in the educational process in the current XXI century, it is not mainly relied on the development of professional skills, upgrade qualifications or retraining as on the formation of decision-making strategies, the timely updating of professional knowledge in parallel with the active inclusion in large-scale social transformation (Kachmar, Barylo, 2020, p. 41). It should be stated that the characteristic features that influence over the formation of the future teacher's method competence are the constant updating of educational mechanisms that dictate terms of the educational process, approaches to the learning organization, components, 
methods, forms of interaction, and lastly the stages of method competence formation. Besides indicated, we should state that the characteristic factors of this concept are the future teachers' clearness of purpose, the desire for professional development, the acquisition of new knowledge, finding new educational resources, ways to obtain educational and methodological information. Within this context, the future educator successfully realizes themselves, provides the optimal approach to the method competence development in the search activities, comprehension of their role in society, continuous self-improvement and selfdevelopment.

Considering the topic importance, creating the conditions also gets special significance. They are necessary for the method competence formation. Describing a future teacher in the making, it should be noted that their success, qualitative transformations of the student's personality, social and professional qualities depend on the educational environment in the higher education institution, on providing optimal conditions for self-improvement and participants' development in the educational process (Sahach, 2019, p. 185). The teacher of the professional pre-higher education institution stimulates students to study, forms professional and method competence, promotes the principles updating, in particular the principle of pedagogical self-teaching, using his own example, pedagogical knowledge, methodical skills, innovative activity, the level of method competence development. The principle of pedagogical self-development is the future teacher's orientation to create conditions for stable satisfaction of their spiritual and pedagogical requirement of self-development and self-realization (Tsiuniak, 2016, p. 43).

Fluent manipulation of methodical skills encourages the teacher to analyze and systematize work in the classroom, to formulate ideas, new thoughts, beliefs, conclusions in a better way. At the same time, it gives him an ability to determine how well the methodological competence of the future teacher is formed. According to the results of training the teacher determines how potential the formation is, since it depends on the further methodical organization of work. In the context of the innovation strategy of the educational process, in the higher education institutions the teacher's role is significantly increasing, because they provide with professional training for the future specialists as an actual carrier of innovative ideas (Tsiuniak, 2018, p. 139). The orientation and formation levels of the future teacher's method competence are a consequence of the conditions created by the lecturer of the education institution. We cannot disagree with I. Humeniuk's opinion that emphasizes that liveliness and innovation, which has become a prominent feature of modern market relations, require high professional and personal qualities of a specialist, as well as a willingness to acquire new experience and overcome stereotypes of thinking (Humeniuk, 2019, p. 52).

The future teachers should realize that with the help of the lecturer they create their own professional skills, knowledge, abilities, pedagogical qualities, activity in professional formation, that all together actively develop their self-esteem. The student himself purposively and deliberately gets involved in finding effective ways of method competence formation. It is clear that the lecturer is the author, tutor, researcher, coach, user and promoter of new pedagogical ideas. As a result, promoted and multifaceted method competence formation becomes fruitful. Realizing the importance of method competence, the own teaching style is formed by a young teacher. Therefore, future educators develop the skills of perseverance, communication skills, competence, self-confidence acquired within training. They have a desire to execute a piece of work in a quality manner, to be open to change, to focus on personal development.

Method competence formation and development can be divided into cycles. In our opinion, the cyclicality of the method competence formation of the teacher occurs throughout the educational period. We believe that the first cycle in the formation of this concept is training in pedagogical institutions of professional pre-higher education (teacher training colleges), where the future teacher acquires some experience during studies and learns to apply the acquired skills within the pedagogical practice. The future teacher's pragmatic readiness and ability for practical activity is formed precisely during the course of practice, and the acquisition process of method competence is formed by imitation of future pedagogical activity. The second cycle of method competence formation includes studies at higher education institutions, where the student continues to acquire new knowledge and consolidate it directly under the guidance of humanities teachers. We believe that the next level of this cyclicality is the application of methodological skills in professional activity when a graduate joins the educational community as an educator. This cyclicality has no end, since work in the educational field is continuous. In the future, being a teacher or a lecturer, an educator face with the principle of "life-long learning", which we interpret as the advanced training, efficiency report, certification, obtaining a qualification category, a scientific degree, an academic title, etc. "Life-long learning" is in effect in all civilized countries today, because in the context of an information society, everyone has a constant lack of knowledge and needs to update it regularly (Markozova, 2016, p. 200). 
Therefore, in accordance with the concept of competence education and the concept of life-long learning, strategic orientation is realized, selfmotivation, self-knowledge, personal responsibility, goal-setting, choice of methods, forms of method competence development become important. This approach meets the requirements in modern times and promotes future teacher's psychological, pedagogical and professional self-development, creates conditions for stimulation, enriches his training and purposeful development of students' creative abilities, prepares the foundation for thoughtful and effective implementation of new technologies through the teaching of humanities (Opaliuk, 2017, p. 435).

Analyzing the scientific opinions of the researchers about this issue, it is found that most of them emphasize that the method competence formation depends largely on the future teachers' personal traits, their ability to implement professional skills. Educational experience that future educators begin to acquire in process of training in educational institutions and continue to improve it in teaching activities is also important for the formation of methodological competence. The teacher's qualitative methodical activity, ability to keep their wits about them in professional changes, work in different directions within the teaching activities, methodical orientation, culture, ethics, brainwork will give new educational results to the future teacher, where knowledge is a necessary condition, and method competence is acquired. It is a kind of tool that will improve the method competence formation on the basis of scientific positions in the theory and practice of pedagogical education. After all, a modern educator must meet international requirements and quality classification in order to fulfill educational functions.

The current educational model requires a more active introduction of method elements and approaches to future professionals' training. Humanities teachers are constantly looking for new ways of forming and improving the method competence development. They introduce innovations in accordance with the current requirements of the legislation and taking into account the most current opinions and studies of both Ukrainian and foreign researchers. In the educational process, new forms and methods of specialists' professional training, new ways of class activity, which help to master and develop sets of crucial, general professional, specialized and professional competences, should be introduced. After all, the main purpose of professional pre-higher education is to make the future specialist a subject of professional activity, capable and ready for personal and professional selfactualization (Stadniichuk, 2019, p. 4-10 ). The importance of professional pre-higher education is to train students for their participation in sociocultural and professional activities, to form their outlook, to develop a system of ideals and values, which determines the personal position of each individual, their attitude to the world and determining their place in it; formation of the educational ideal of the future national elite of the country (Yershova, 2015, p. 123).

Conclusions. The methodological principles of the method competence formation of future teachers in professional pre-higher education institutions are based on the strategic problem of reforming the education system in Ukraine, since the preparation of the methodologically competent teacher is relevant now. There is no need to discuss which approach is more effective or advanced in order to form the future professionalism's method competence, since it is based on his successful adaptation to pedagogical activity in the current conditions of European integration to the Ukrainian education. The analysis of the scientific methodological literature gives grounds to claim that there is no single approach to define the very concept of the method competence development. We believe that the technology of the method competence formation of future teachers in professional pre-higher education institutions in accordance with the cycles (stages) of professional development needs refinement. We believe that further study of the model of method competence formation and development of future educators and teachers of humanities, their implementation and the impact of innovative processes on the formation level also deserve to be studied.

\section{References}

Гуменюк, I., 2019. Формування підприємницької компетентності майбутніх фахівців педагогічного профілю. Педагогічна освіта: теорія і практика, 26(1), с. 52-57. doi: http://doi.org/10.32626/2309-9763.2019-26-1.52-57

Галай, В., 2010. Розвиток методичної компетентності вчителів технологій в умовах модернізації вищої освіmи. [online] Доступно: $<$ http//library.udpu.rg.ua/labrari_files/zbirnuk_nayk_praz/2010/2010_2_11.pdf.> [Дата 3вернення 03 Березень 2020].

Замкова, I.I., 2015. Модель сучасного вчителя (творчий проект). [online]. Доступно: <http://osvita-verh.dp.ua/ files/2015/Zamkova.pdf.> [Дата зверненя 03 Березень 2020].

Заболотна, М., 2014. Структура методичної компетентності викладачів професійно-теоретичної підготовки ПТНЗ гірничого профілю. Вісник післядипломної освіти, 11, с. 61-70. 
Єршова, Л., 2015. Формування референтної особистості як проблема освітньої практики сучасної України. Вісник Черкаського національного університету. Педагогічні науки, 6 (339), с. 119-124.

Качмар, О.В. та Барило, С.Б., 2020. Роль безперервного навчання у соціально-економічному розвитку України у XXI столітті. Інновачійна педагогіка, 20, с. 41-45.

Кучерявий, О.Г., 2015. Кар'єрне зростання: особистісний вимір: монографія. Київ: Видавничий дім "Слово". 224 c.

Маркозова, О.О, 2016. Навчання впродовж життя - необхідна передумова досягнення життєвого успіху людини. Вісник Національного університету "Юридична академія Украӥни імені Ярослава Мудрого", 2 (29), с. $198-204$.

Опалюк, Т.Л., 2017. Дидактичний потенціал гуманітарних дисциплін щодо формування соціальної рефлексії майбутніх вчителів. Молодий вчений, 12 (52), с. 433-437.

Сагач, О., 2019. Закономірності формування студента як суб'єкта неперервного зростання. Педагогічна освіта: теорія і практика, 26 (1.), с. 183-188. doi: http://doi.org/10.32626/2309-9763.2019-26-1.183-188,

Сімоненко, Л.Ю., 2013. Методична компетентність як складник професійної компетентності вчителя української мови. Науковий вісник Донбасу, 2. [online] Доступно: <http://nbuv.gov.ua/UJRN/nvd_2013_2_28> [Дата зверненя 03 Березень 2020].

Стаднійчук, I., 2019. Методичні засади формування професійної компетентності майбутніх техніків-електриків в аграрних коледжах. Науковий вісник Інституту професійно-технічної освіти НАПН Украӥни. Професійна педагогіка, 2 (19), с. 4-10. doi: https://doi.org/10.32835/2223-5752.2019.19.4-10.

Цюняк, О.П., 2016. Формування професійной культури майбутніх магістрів початкової освіти у вищих навчальних закладах: монографія. Івано-Франківськ: Ярина.

Цюняк, О.П., 2018. Деякі аспекти формування професійної готовності майбутніх магістрів початкової освіти до інноваційної діяльності в закладах вищої освіти. Гірська школа украӥнських Kapnam, 18, c. 137-143. doi: https:// doi.org/10.15330/msuc.2018.18.142-147

\section{Translated \& Transliterated}

Humenyuk, I., 2019. Formuvannya pidpryyemnytskoyi kompetentnosti maybutnikh fakhivtsiv pedahohichnoho profilyu [Entrepreneurial competence formation of future specialists in pedagogical profile] Pedahohichna osvita: teoriya i praktyka [Entrepreneurial competence formation of future specialists in pedagogical profile], 26 (1), s. 52-57. doi: http://doi.org/ 10.32626/2309-9763.2019-26-1.52-57, [in Ukrainian].

Halay V., 2010. Rozvytok metodychnoyi kompetentnosti vchyteliv tekhnolohiy v umovakh modernizatsiyi vyshchoyi osvity [Method competence development of technology teachers in the context of higher education modernization]. [online] Dostupno: <http//library.udpu.rg.ua/labrari_files/zbirnuk_nayk_praz/2010/2010_2_11.pdf $>$ [Data zvernenia 03 Berezen 2020], [in Ukrainian].

Zamkova, I.I., 2015. Model'suchasnoho vchytelya (tvorchyy proekt) [Model of the modern teacher (creative project)]. [online] Dostupno: <http://osvita-verh.dp.ua/files/2015/Zamkova.pdf.> [Data zvernennia 14 April 2020], [in Ukrainian].

Zabolotna, M., 2014. Struktura metodychnoyi kompetentnosti vykladachiv profesiyno-teoretychnoyi pidhotovky PTNZ hirnychoho profilyu [The structure of methodikal competence of teachers of professional and theoretikal training of Vocational education with mining profile]. Visnyk pisliadyplomnoi osvity [Bulletin of postgraduate education], 11, s. 61-70, [in Ukrainian].

Yershova, L., 2015. Formuvannya referentnoyi osobystosti yak problema osvitnoyi praktyky suchasnoyi Ukrayiny [Formation of a reference person as a problem of educational practice in modern Ukraine.]. Visnyk Cherkaskoho natsionalnoho universytetu. Pedahohichni nauky [Bulletin of Cherkasy National University. Pedagogical Sciences], 6 (339), s. 119-124, [in Ukrainian].

Kachmar, O.V. ta Barylo, S.B., 2020. Rol bezperervnoho navchannya u sotsial?no-ekonomichnomu rozvytku Ukrayiny $\mathrm{u}$ KHKHI stolitti [The role of life-long learning in the socioeconomic development of Ukraine in the 21 st century]. Innovatsiyna pedahohika [Innovative Pedagogy], 20, s. 41-45, [in Ukrainian].

Kucheryavyy, O.H., 2015. Karyerne zrostannya: osobystisnyy vymir: Monohrafiya [Career Opportunities: A Personal Dimension: Monograph]. Kyiv: Vydavnychyy dim "Slovo"[Publishing House "Slovo"], [in Ukrainian].

Markozova, O.O, 2016. Navchannya vprodovzh zhyttya - neobkhidna peredumova dosyahnennya zhyttyevoho uspikhu lyudyny [Life-long learning is a necessary supposition for achieving a person's life success]. Visnyk Natsionalnoho universytetu "Yurydychna akademiya Ukrayiny imeni Yaroslava Mudroho" [Bulletin of the Yaroslav Mudryi Ukrainian National Law University], 2 (29), s. 198-204, [in Ukrainian].

Opalyuk, T.L., 2017. Dydaktychnyy potentsial humanitarnykh dystsyplin shchodo formuvannya sotsialnoyi refleksiyi maybutnikh vchyteliv [The didactic potential of the humanities to form the future teachers' social reflection]. Molodyy vchenyy [Young Scientist], 12 (52), s. 433-437, [in Ukrainian].

Sahach, O., 2019. Zakonomirnosti formuvannya studenta yak subyekta neperervnoho zrostannya [Regularities of the student's formation as a subject of continuous growth]. Pedahohichna osvita: teoriya i praktyka [Teacher education: theory and practice.]. 26 (1.), s. 183-188, [in Ukrainian]. doi: http://doi.org/10.32626/2309-9763.2019-26-1.183-188.

Simonenko, L. Y., 2013. Metodychna kompetentnist yak skladnyk profesiynoyi kompetentnosti vchytelya ukrayinskoyi movy [Method competence as a component of professional competence of the Ukrainian language teacher]. Naukovyy visnyk Donbasu [Scientific Bulletin of Donbass], [online] 2. Dostupno: http://nbuv.gov.ua/UJRN/nvd_2013_2_28. [Data zvernennia 14 April 2020], [in Ukrainian].

Stadniychuk, I., 2019. Metodychni zasady formuvannya profesiynoyi kompetentnosti maybutnikh tekhnikiv-elektrykiv v ahrarnykh koledzhakh [Methodical bases of professional competence formation of future electrical technicians in agricultural colleges]. Naukovyy visnyk Instytutu profesiyno-tekhnichnoyi osvity NAPN Ukrayiny. Profesiyna pedahohika [Scientific Bulletin of the Institute of Vocational Education of the National Academy of Pedagogical Sciences of Ukraine. Professional Pedagogy], 2 (19), s. 4-10, doi: https://doi.org/10.32835/2223-5752.2019.19.4-10, [in Ukrainian]. 
Tsyunyak, O.P., 2016. Formuvannya profesiynoyi kultury maybutnikh mahistriv pochatkovoyi osvity u vyshchykh navchalnykh zakladakh: Monohrafiya [Professional culture formation of future masters of elementary education in higher educational establishments: Monograph]. Ivano-Frankivsk: Yaryna., [in Ukrainian].

Tsyunyak, O.P., 2018. Deyaki aspekty formuvannya profesiynoyi hotovnosti maybutnikh mahistriv pochatkovoyi osvity do innovatsiynoyi diyalnosti $\mathrm{v}$ zakladakh vyshchoyi osvity [Some aspects of professional readiness formation of future masters of elementary education to innovative activity in higher educationinstitutions]. Hirska shkola ukrayinskykh Karpat [Mountain School of the Ukrainian Carpathians], 18, c. 137-143., doi: https://doi.org/10.15330/msuc.2018.18.142-147, [in Ukrainian].

УДК: 378:37.011.3-051:[37.091.33:005.336.2]

\section{Формування методичної компетентності майбутнього педагога}

\section{Людмила Ликтей}

методист, викладач, спеціаліст вищої категорії Івано-Франківського коледжу ДВНЗ "Прикарпатський національний університет імені В.Стефаника" e-mail: L.liktej@ukr.net

\section{Реферат.}

Актуальність даного дослідження полягає в необхідності обгрунтування методологічних засад формування методичної компетентності майбутнього педагога через розвиток методичної компетентності викладачів гуманітарних дисциплін педагогічних коледжів у процесі викладання дисциплін гуманітарного спрямування.

Мета дослідження полягає в обгрунтуванні та висвітленні проблем формування методичної компетентності майбутніх педагогів у педагогічних закладах фахової передвищої освіти України.

Методи: теоретичні (вивчення й аналіз філософської, психологічної та педагогічної літератури, порівняння й узагальнення теоретичних концепцій педагогічного досвіду роботи викладачів гуманітарних дисциплін, пріоритетних ідей науковців щодо вирішення проблеми формування методичної компетентності майбутніх педагогів; емпіричні (методи самооцінювання; експертного оцінювання); статистичні (частковий аналіз перевірки статистичних гіпотез).

Результати: у статті виокремлено низку думок науковців, що становлять поєднання результатів розвитку методичної компетентності, методичного досвіду та особистісних рис, які являють собою професійний баланс та інтеграційний освітній курс. Проаналізовано ряд гіпотез, які відомі науковій розвідці щодо формування методичної компетентності майбутніх педагогів, розглянуто їх суть. Це дало змогу встановити основні вимоги щодо розвитку методичної компетентності від витоків ії зародження до професійного застосування на практиці. Безумовно, що ефективне формування методичної компетентності в майбутніх педагогів базується, насамперед, на мотиваційних переконаннях, особистісному усвідомленні значущості обраної професії, бажанні набуття професійного та методичного досвіду. Паралельно, важливого значення набуває і розвиток методичної компетентності викладачів гуманітарних дисциплін педагогічних коледжів, підвищення професійних якостей, методичної культури, прагнення до впровадження та застосування інноваційних методів роботи в освітньому процесі, спрямованих на розвиток, навчання, освіту педагога-початківця.

Висновки: методологічні засади формування та розвитку методичної компетентності майбутніх педагогів повинні грунтуватися на сформованості професійно важливих і першочергових для належного провадження освітнього процесу, якостях, розумінні та усвідомленні суті, змісту, цілей, завдань педагогічної освіти. Володіння низкою педагогічних знань, методичних умінь та навичок, оволодіння методами та способами розв'язання педагогічних завдань, які сприяють прагненню до підвищення педагогічної кваліфікації, професійної та методичної компетентностей.

Ключові слова: методична компетентність, розвиток методичної компетентності, викладач, педагог, освіта. 